\title{
HUBUNGAN MOTIVASI PEMBELAJARAN OLEH GURU KELAS TERHADAP NILAI RAPORT SISWA DI SEKOLAH DASAR NEGERI
}

\author{
Sogi Hermanto \\ Prodi Manajemen Pendidikan FKIP Universitas Palangka Raya \\ e-mail: 1953sogi12@gmail.com
}

\begin{abstract}
Abstrak : Tujuan penelitian ini untuk mengetahui: (1) deskripsi motivasi pembelajaran oleh guru kelas, (2) deskripsi nilai raport siswa, dan (3) hubungan antara motivasi pembelajaran oleh guru kelas terhadap nilai raport siswa. Populasi penelitian ini adalah guru kelas di 14 (empat belas) Sekolah Dasar Negeri di Kelurahan Palangka di Kota Palangka Raya sebanyak 84 orang yang ditarik sebagai sampel total. Populasi siswa sebanyak 2792 siswa, sampel diambil 15\% dari populasi diperoleh 419 siswa, dan untuk mendapatkan sampel secara proposional dari masing kelas digunakan teknik proposional random sampling sehingga diperoleh sampel 84 siswa. Hasil penelitian diperoleh bahwa: (1) deskripsi motivasi pembelajaran oleh guru kelas di SDN yang tertinggi dalam kategori "Baik", (2) deskripsi Nilai Raport Siswa tertinggi dalam kategori "Baik", dan (3) ada korelasi positif yang signifikan antara motivasi pembelajaran oleh guru kelas terhadap Nilai Raport Siswa di Sekolah Dasar Negeri (SDN) se Kelurahan Palangka di Kota Palangka Raya.
\end{abstract}

Kata kunci : motivasi pembelajaran, guru kelas, nilai raport siswa

Pendidikan dan pengajaran adalah suatu proses yang sadar tujuan, maksudnya adalah bahwa kegiatan belajar mengajar itu suatu peristiwa yang terkait, terarah pada tujuan. Dimana tujuan pendidikan dan pengajaran dikenal adanya tujuan akhir dan tujuan intermedier, hal ini dijadikan dasar motivasi untuk mencapai tujuan dalam rangka mencerdaskan kehidupan bangsa dan membentuk watak serta peradapan bangsa yang bermartabat.

Nilai raport disebut juga nilai final baik berupa angka atau huruf. Nilai yang melambangkan tingkat keberhasilan peserta didik setelah mereka mengikuti program pendidikan pada jenjang pendidikan tertentu dan dalam jangka waktu yang telah ditentukan. Pemberian nilai akhir merupakan umpan balik yang mencerminkan seberapa jauh peserta didik telah dapat mencapai tujuan yang telah ditentukan. Jika pemberian nilai akhir itu dapat dilaksanakan dengan baik, tepat, dan objektif, maka akan diketahui pula keberhasilan atau ketidak berhasilan peserta didik pada setiap tujuan pengajaran.

Tujuan yang lebih penting dalam pembelajaran adalah bagaimana untuk mengusahakan agar perkembangan dan motivasi pembelajaran siswa yang diberikan oleh guru dapat mencapai hasil pada tingkat yang optimal. Secara instruksional pemberian nilai akhir merupakan umpan balik yang mencerminkan seberapa jauh siswa telah dapat mencapai tujuan yang telah ditentukan. Jika pemberian nilai akhir itu dapat dilaksanakan dengan baik, tepat, dan objektif, maka akan diketahui pula keberhasilan atau ketidak berhasilan siswa pada setiap bagian dari tujuan pengajaran tersebut.

Peraturan Pemerintah Republik Indonesia Nomor 19 Tahun 2005 tentang Standar Nasional Pendidikan Bab VII, Pasal 58, Ayat (1) dan (2) disebutkan bahwa pada Ayat (1) yaitu pelaporan dilakukan oleh pihak pendidik, tenaga kependidikan, pimpinan satuan pendidikan, dan pengawas atau penilik satuan pendidikan; Ayat (2) yaitu pada jenjang pendidikan dasar dan menengah, laporan oleh pendidik ditujukan kepada pimpinan satuan pendidikan dan orang tua/wali pesrta didik, berisi hasil evaluasi dan penilaian sebagaimana dimaksud pada ayat (1) dan dilakukan sekurang-kurangnya setiap akhir semester. 
Peranan motivasi dalam kegiatan pem-belajaran baik intrinsik maupun ektrinsik sangat diperlukan. Motivasi bagi peserta didik dapat mengembangkan aktivitas dan inisiatif, dapat mengarahkan dan memelihara ketekunan dalam melakukan kegiatan belajar. Dalam kaitan itu perlu diketahui bahwa cara dan jenis menumbuhkan motivasi adalah bermacam-macam. Akan tetapi untuk motivasi ekstrinsik kadang-kadang tepat, kadang-kadang juga bisa kurang sesuai. Hal ini peranan guru harus hati-hati dalam menumbuhkan dan memberikan motivasi kegiatan pembelajaran bagi peserta didik. Dalam kegiatan pembelajaran peserta didik sangat diperlukan adanya motivasi "Motivation is an essential condition of learning". Makin tepat motivasi yang diberikan, akan makin berhasil pembelajaran itu. Sehingga motivasi akan senantiasa menentukan intensitas usaha belajar bagi peserta didik.

Sardiman (2003) menyatakan bahwa motivasi dapat juga dikatakan serangkaian usaha untuk menyediakan kondisi-kondisi tertentu, sehingga seseorang itu mau dan ingin melakukan sesuatu, dan bila ia tidak suka, maka akan berusaha untuk meniadakan atau mengelakkan perasaan tidak suka itu". Sejalan dengan pendapat di atas Mc. Donald (2003) menyatakan bahwa motivasi adalah perubahan energi dalam diri seseorang yang ditandai dengan munculnya "feeling" dan didahului dengan tanggapan dengan adanya tujuan.

Sistem pendidikan yang terarah dan terpadu, usaha penilaian tidak dapat dipisahkan dari keseluruhan penyelenggaraan pendidikan. Bahkan antara pengajaran dan penilaian terdapat pengaruh timbal balik. Prosedur penilaian tertentu menuntut terselenggaranya program pengajaran yang sesuai. Sebaliknya suatu pendekatan pengajaran dengan kekhususan tertentu, menuntut usaha-usaha penilaian yang tetentu pula. Jika nilai raport yang dilakukan oleh guru kelas baik, maka peserta didik akan termotivasi untuk belajar. Begitu pula sebaliknya jika nilai raport yang dilakukan oleh guru kelas kurang baik, maka peserta didik kurang termotivasi untuk belajar.

Selain nilai hasil belajar yang dicapai oleh peserta didik, ada juga faktor motivasi perlu mendapat pertimbangan dalam rangka penentuan nilai akhir baik nilai yang rendah maupun nilai yang tinggi. Sebaliknya bagi peserta didik yang memiliki nilai prestasi rendah, tetapi dengan nilai yang rendah tersebut tidak ada motivasi dan upaya yang positif untuk memperbaiki diri, suka membolos, tugas-tugas tidak dikerjakan, maka nilai akhirnya akan diberikan menurut apa adanya. Tidak hanya itu prestasi juga digunakan sebagai satu bahan untuk melakukan pertimbangan dalam penentuan nilai akhir dan sebagai pemicu peningkatan motivasi belajar peserta didik. Sebab prestasi dilambangkan dengan nilai-nilai hasil belajar yang pada dasarnya mencerminkan sampai sejauh mana tingkat keberhasilan yang telah dicapai oleh peserta didik. Prestasi juga mencerminkan pencapaian tujuan pendidikan dan peningkatan motivasi belajar siswa yang telah ditentukan bagi setiap mata pelajaran.

\section{METODE}

Penelitian ini menggunakan pendekatan kuantitatif. Pendekatan kuantitatif merupakan gejala-gejala hasil pengamatan yang berwujud data diukur dan diwujudkan dalam bentuk angka dan dianalisa dengan teknik statistik. Sedang ditinjau dari pola atau sifat penelitian termasuk dalam penelitian deskriptif korelasi, karena peneliti berusaha menelaah hubungan antara satu variabel dengan variabel lainnya. Menurut Suryabrata (1993) menyatakan bahwa tujuan penelitian korelasional adalah untuk mendeteksi sejauh mana variasi-variasi pada satu atau lebih faktor lain berdasarkan koefisien korelasi.

Penelitian ini dilakukan di Sekolah Dasar Negeri (SDN) se Kelurahan Palangka di Kota Palangka Raya. Sebagai populasi dan sampel adalah guru kelas dan siswa. Populasi untuk guru dalam penelitian ini adalah guru kelas yang berasal dari 14 (empat belas) Sekolah Dasar Negeri di Kelurahan Palangka di Kota Palangka Raya sebanyak 84 orang yang ditarik sebagai sampel total. Sedangkan sebagai populasi untuk siswa di 14 (empat belas) Sekolah Dasar Negeri di Kelurahan Palangka di Kota Palangka Raya sebanyak 2792 siswa, sampel diambil 15\% dari populasi diperoleh 419 siswa, dan untuk mendapatkan sampel secara proposional dari masing kelas digunakan teknik proposional random sampling dengan rumus dari pendapat (Rasyid, 1993), sehingga diperoleh sampel sebanyak 84 siswa.

Data diambil dengan menggunakan angket tertutup, observasi, dokumentasi. Validitas 
angket dilihat dari validitas isi (content validity). Sedangkan reliabilitas dihitung setelah angket diujicobakan dengan menggunakan rumus Alpa. Angket diujicobakan kepada guru Sekolah Dasar Negeri Kelurahan Palangka Kota Palangka Raya yang tidak dikenakan sebagai sampel penelitian. Angket disusun dengan model skala likert. Untuk angket motivasi pembelajaran oleh guru kelas berjumlah 28 butir pertanyaan, dan angket nilai raport siswa adalah nilai raport siswa kelas I - VI.

Data yang diperoleh, selanjutnya dianalisis dengan menggunakan teknik analisis deskriptif kuantitatif yang digambarkan dalam bentuk distribusi frekuensi terhadap kategori-kategori skala penilaian yang telah ditentukan. Uji hipotesis menggunakan rumus Product Moment dari Pearson. Dari hasil analisis tersebut kemudian dideskripsikan untuk mengambil kesimpulan tentang masing-masing indikator berdasarkan kriteriannya.

\section{HASIL}

\section{Deskripsi Motivasi Pembelajaran oleh Guru Kelas}

Angket motivasi pembelajaran oleh guru kelas berjumlah 28 butir pertanyaan yang disebarkan terhadap 84 orang guru, dengan target nilai paling tinggi 112 dan paling rendah 28. Berdasarkan data yang terkumpul diketahui bahwa nilai tertinggi yang diperoleh dari responden adalah 112 dan nilai terendah adalah 88. Distribusi data motivasi pembelajaran oleh guru kelas tertera pada Tabel 1.

Tabel 1. Distribusi Data Motivasi Pembelajaran oleh Guru Kelas (X)

\begin{tabular}{lllll}
\hline No. & Interval & $\begin{array}{l}\text { Kategori } \\
\text { (k) }\end{array}$ & $\begin{array}{l}\text { Frekuensi } \\
\text { (f) }\end{array}$ & \% \\
\hline 1. & $107-112$ & Amat Baik & 17 & 20,24 \\
2. & $101-106$ & Baik & 54 & 64,29 \\
3. & $95-100$ & Cukup & 8 & 9,52 \\
4. & $88-94$ & Kurang & 3 & 5,95 \\
\hline
\end{tabular}

Berdasarkan Tabel 1 di atas, dapat diketahui bahwa motivasi pembelajaran oleh guru kelas di sekolah dasar negeri se Kelurahan Palangka Kota Palangka Raya berada dalam kategori "Amat Baik" sebanyak 20,24\% (17 guru kelas) dengan skor antara 107 - 112, nilai kategori "Baik" mendapatkan persentase $64,29 \%$ (54 guru kelas) dengan skor antara 101 - 106, nilai kategori "Cukup" dengan mendapatkan persentase 9,52\% (8 guru kelas) dengan skor antara 95 - 100, dan nilai kategori "Kurang" dengan mendapatkan persentase $5,95 \%$ (3 guru kelas) dengan skor antara 88 - 94.

\section{Deskripsi data Nilai Raport siswa}

Nilai raport siswa diambil dari kelas I - VI dengan sampel sejumlah 84 siswa dari 14 sekolah, di Sekolah Dasar Negeri se Kelurahan Palangka Kota Palangka Raya, dengan target nilai paling tinggi 100 dan paling rendah 0 . Berdasarkan hasil data yang terkumpul diketahui bahwa nilai tertinggi yang diperoleh dari responden adalah 85 dan nilai terendah adalah 65. Distribusi data nilai raport siswa tertera pada Tabel 2.

Tabel 2. Distribusi Data Nilai Raport Siswa (Y)

\begin{tabular}{lllll}
\hline No & Interval & $\begin{array}{l}\text { Kategori } \\
\text { (k) }\end{array}$ & $\begin{array}{l}\text { Frekuensi } \\
\text { (f) }\end{array}$ & \% \\
\hline 1 & $80-85$ & Baik Sekali & 23 & 27,40 \\
2 & $75-79$ & Baik & 27 & 32,14 \\
3 & $70-74$ & Cukup & 18 & 21,38 \\
4 & $65-69$ & Kurang & 16 & 19,08 \\
\hline
\end{tabular}

Berdasarkan tabulasi pada Tabel 2 di atas, dapat diketahui bahwa nilai raport siswa pada Sekolah Dasar Negeri se Kelurahan Palangka Kota Palangka Raya berada dalam nilai kategori "Baik Sekali" sebanyak 27,40\% (23 siswa) dengan skor antara 80 - 85, nilai kategori "Baik" sebanyak $32,14 \%$ (27 siswa) dengan skor antara 75 - 79, nilai kategori "Cukup" sebanyak 21,38\% (18 siswa) dengan skor antara $70-74$, dan nilai kategori "Kurang" sebanyak 19,08\% (16 siswa) dengan skor antara 65 - 69.

\section{Pengujian Hipotesis}

Hipotesis dalam penelitian ini diuji dengan menggunakan rumus Product Moment dari Pearson. Uji ini untuk melihat hubungan antara variabel motivasi pembelajaran oleh guru kelas (X) dengan variabel nilai raport siswa (Y). Berdasarkan perhitungan, diperoleh rxy hitung = 0,827 . Dengan rxy hitung 0,827 adalah lebih besar dari $r$ tabel $=0,213$ pada taraf signifikan 5\% dan taraf signifikan $1 \%=0,278$, maka Ha diterima, dan Ho ditolak. Berarti ada hubungan positif yang signifikan antara motivasi pembelajaran oleh guru kelas terhadap nilai raport siswa di SDN se Kelurahan Palangka Kota Palangka Raya. 


\section{PEMBAHASAN}

Pembahasan penelitian ini difokuskan pada pembahasan pada hasil pengujian hipotesis dari motivasi pembelajaran oleh guru kelas terhadap nilai raport siswa di SDN se Kelurahan Palangka Kota Palangka Raya. Hasil penelitian menunjukkan bahwa ada hubungan yang positif antara motivasi pembelajaran oleh guru kelas terhadap nilai raport siswa di SDN se Kelurahan Palangka Kota Palangka Raya. Dengan demikian bahwa dalam penelitian ini motivasi pembelajaran oleh guru kelas dapat mempengaruhi nilai raport siswa.

Pola hubungan yang terdapat antara variabel bebas $(\mathrm{X})$ dan variabel terikat $(\mathrm{Y})$ dapat digambarkan sebagai berikut:

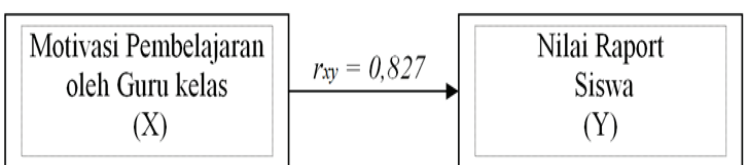

Gambar 1. Hubungan antara Variabel Bebas X dan Variabel Terikat Y

Hasil perhitungan menunjukkan angka hubungan (korelasi) antara variabel $\mathrm{X}$ (variabel bebas) dan variabel $Y$ (variabel terikat) tidak bertanda negatif, berarti diantara kedua variabel tersebut terdapat hubungan positif (korelasi berjalan searah). Dengan demikian memperhatikan besarnya rxy $=0,827$. Apabila hasilnya berkisar antara $0,70-0,90$ berarti korelasi antara variabel $\mathrm{x}$ dan variabel $\mathrm{y}$, termasuk korelasi positif yang kuat/tinggi.

\section{KESIMPULAN DAN SARAN}

\section{Kesimpulan}

Berdasarkan hasil analisis data dapat disimpulkan bahwa: (1) motivasi pembelajaran oleh guru kelas memiliki nilai kategori "Amat Baik" dan "Baik", berarti motivasi pembelajaran oleh guru kelas itu adalah sangat penting, (2) nilai raport siswa memiliki kategori "Baik Sekali" dan kategori "baik", ini berarti nilai raport siswa sangat dipengaruhi motivasi pembelajaran oleh guru kelas, (3) terdapat hubungan positif yang signifikan antara motivasi pembelajaran oleh guru kelas terhadap nilai raport siswa di SDN se Kelurahan Palangka Kota Palangka Raya secara langsung yang sangat kuat/tinggi.

\section{Saran}

Saran ditujukan kepada: (1) Kepala Sekolah diharapkan agar memberi respon atau tanggapan kepada guru-guru dalam menjalin kerjasama dengan guru kelas dan siswa guna meningkatkan motivasi siswa supaya dapat terjalin hubungan dengan baik, (2) bagi guru diharapkan adanya hubungan motivasi pembelajaran oleh guru kelas terhadap nilai raport siswa di SDN se Kelurahan Palangka Kota Palangka Raya yang sudah dilakukan dengan baik tersebut, hendaknya dipertahankan dan lebih ditingkatkan guna perbaikan mutu dan peningkatan kualitas belajar siswa, dan (3) bagi peserta didik diharapkan mampu memberikan pengetahuan akan kemajuan-kemajuan yang telah dicapai pada umumnya yang berpengaruh baik pekerjaan selanjutnya, artinya prestasi yang selanjutnya lebih baik.

\section{DAFTAR RUJUKAN}

A.M. Sardiman, 2003. Interaksi dan Motivasi Belajar Mengajar. Jakarta: PT Raja Grafindo Persada.

Al Rasyid, H. 1993. Teknik Penarikan Sampel dan Penyusunan Skala. Bandung: Pasca Sarjana UNPAD.

Mc. Donald, 2003. Educational Psychology. San Fransisco: Overseas Publiscations, Ltd.

Peraturan Pemerintah Republik Indonesia Nomor 19 Tahun 2005 tentang Standar Nasional Pendidikan. Jakarta: Kepala Biro Tata Usaha.

Suryabrata, S. 2004. Psikologi Pendidikan. Jakarta: PT. Raja Grafindo. Persada. 